\title{
Financial Instruments Reflected by Organizations in Accordance with International Standards of Financial Accounting of Public Sector
}

\author{
Svetlana Vasilyevna Ponomareva
}

Anna Sergeevna Melnikova

\author{
Perm National Research Polytechnic University, 614990, Perm, Russian Federation \\ 614990, Perm, Russian Federation, 29 Komsomolsky Ave., Bldg.B, Office 306, \\ Email: psvpon@mail.ru
}

\section{Doi:10.5901/mjss.2015.v6n3s3p213}

\section{Abstract}

In the paper conceptual and methodic problems of international standards of financial accounting of public sector implementation into economical activity of governmental organizations of the Russian Federations are considered. The implementation of international standards in Russia is the first step for principal reforming of attitude towards incomes/expenses, deficit/surplus in organizations of government (public) sector of national economy. Authors have researched financial instruments used in activity of public sector's organizations. In the article basic accounting instrumentation for estimation of loans and receivables, subsequent appraisal of investments in equity instruments, author's formulas on calculation of investments and identification of fair value from withdrawal of the financial asset are particularly examined, author's formulas on calculation of subsequent assessment of financial instruments by four typical categories.

Keywords: international standards of financial reporting, financial instruments, financial assets, financial obligations, author's formula, transformation.

\section{Introduction}

\subsection{IntroducetheProblem}

The relevance of research topic relates to the fact that structural crisis in Russia had highlighted the importance of reliable and timely financial information represented by economically significant constituents of the country for provision of global economical and financial stability in the world. In Russia the international standards of financial accounting of public sector approved by Ministry of Finance of the Russian Federation in 2013 were introduced to financial activity starting from 2014 or can be applied later, Recent crisis has revealed disadvantages referred just as to the structure of financial accounting, so to inadequacy of economical structure as the whole. The information that will be reflected in international standards of financial accounting of public sector will mean responsibility of government for results of work at all the levels of governmental authority.

\subsection{Importance of the Problem}

Conceptual and methodic problems concerned in the present research work are of special importance for organizations of budget sphere in the Russian Federation, as far as they are being basic when transforming Russian accounting in accordance with requirements of international standards.

\subsection{Relevant Scholarship}

The research topic is not quite developed in national and foreign literature. Scientific polemic in the area of transformation of financial accounting is almost not performed by public sector, as far as the standards were adopted and published in Russia in 2014, however studies in this area of knowledge have already been conducting by the following specialists: Tabalina S.A. (2001), Gradutsky A.G. (2012), Dombrovskaya E.N. (2012). Substantial contribution to Scientific polemic on ISFR of public sector at international level was made by James L. Chan (2008).

1.4 State Hypotheses and Their Correspondence to Research Design 
The main hypothesis is that when applying methods and instrumentation for formation of data about financial instruments developed by authors will simplify the task of financial and economical services in case of transformation of accounting in accordance with ISFR of public sector. The qualitative information represented in financial accounting by organizations of public sector can be used for planning and modeling of financial resources being necessary for activity of subject of government management sector and also for financial resources and operations linked to the risks and current type of Russian economy - the Economy of uncertainty.

\section{Method}

Authors carried out the present research used the following methods:

1. Abstract method (i.e., authors of the paper abstracted from available material on the research topic).

2. Hypothetico-induction method (i.e. the obtained auxiliary results of the research were generalized by authors).

3. Hypothetico-deduction cognition method (i.e. general aspects of preparation of financial accounting in accordance with ISFR of public sector by the organizations of public sector and particular aspects of financial instruments reflection are considered, simulation method is also used.

For organizations, activity of which is defined by budget financing or realization of goods and services on noncommercial basis, the International Federation of Accountants (hereinafter referred to as IFAC) has developed special standards of financial accounting of public sector. The international public sector accounting standards (IPSAS) were made by the following organizations (see fig. 1).

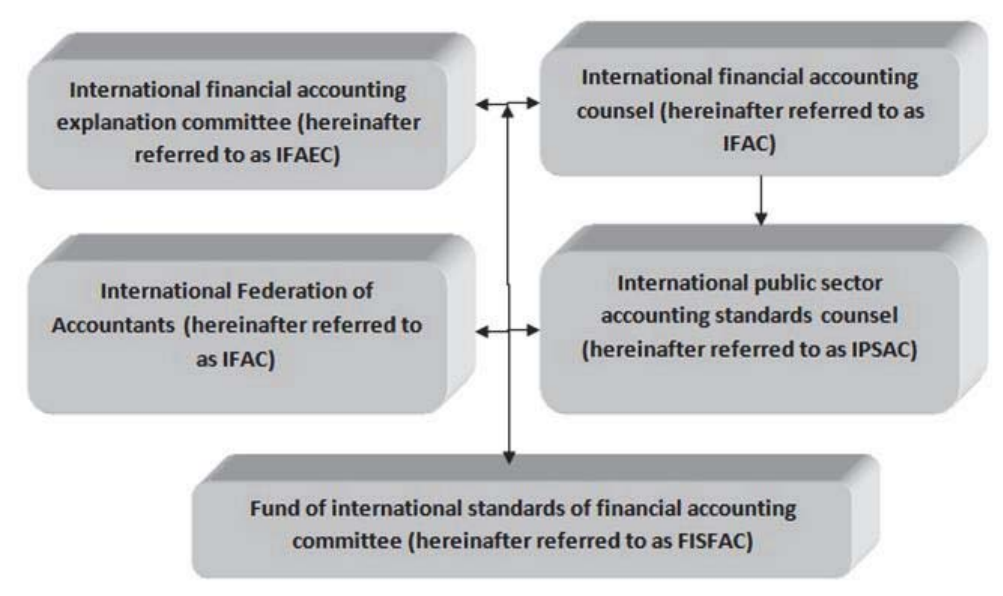

Figure 1 - Organizations forming and influencing adoption of international standards of financial accounting of public sector

In addition the significant influence on adoption of decisions on international standards of financial accounting of public sector was asserted by such organizations as:

1. Organization for Economic Cooperation and Development.

2. World Bank.

3. Financial Stabilization Counsel.

4. International Organization of Securities Commissions.

5. International Monetary Fund.

6. International Counsel on Ethic Standards for Accountants.

7. International Counsel on Standards of Auditorial and Insurance Activities.

8. Public Sector Committee.

9. International Auditors' Committee.

10. Other organizations.

By considering international aspects of adoption of regulatory framework we can reconstruct the dynamics of their development in retrospective key (see Table 1). 
Table 1. Dynamics of adoption of regulatory framework on financial instruments by date of approval of standard and date of application by organizations

\begin{tabular}{|c|c|c|}
\hline ISFAC & IFAC & IPSAC and FISFAC \\
\hline IAS & IFRS & IPSAS \\
\hline IAS 32 (25.11.2011), 07.05.2013 & IFRS 7 (25.11.2011), 07.05.2013 & IPSAS 15 (12.2001), 01.07.2003 \\
\hline \multirow{3}{*}{ IAS 39 (25.11.2011), 17.12.2014 } & \multirow{3}{*}{ IFRS 9 (01.01.2015) } & IPSAS 28 (01.2010) \\
\cline { 3 - 3 } & & IPSAS 29 (01.2010) \\
\cline { 3 - 3 } & & IPSAS 30 (01.2013) \\
\hline
\end{tabular}

Relying on the collected data listed in the table next we will represent the retrospective dynamic model of adoption of standards on financial instruments (see fig. 2).

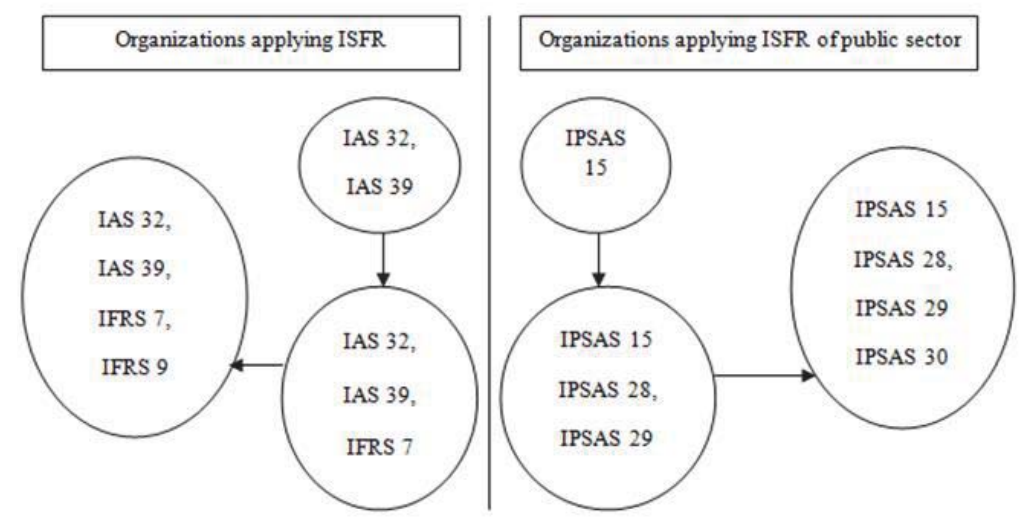

Figure 2 - Retrospective dynamic model of adoption of standards on formation and approval of financial instruments

Let's consider the goals of creation of international standards of financial accounting of public sector:

1. Unification of rules for representing accounting financial information of public sector's organizations.

2. Realization of accountability principle.

3. Improvement of quality of accounting information for adoption of more justified decisions concerning resources allocation.

4. Ultimate subdivision of accounting into: financial, administrative and fiscal.

5. Provision of financial flows' visibility.

6. Standardization of cost calculation techniques.

7. Standardization of approaches to proficits (deficits) of budgets.

8. Provision of general approaches to accounting of governmental capital investments and property.

9. Provision of identity of basic accounting principles of ISFA and international standards of financial accounting of public sector for convenience of professional users.

The main task of corporation that perform accounting on the basis of international standards of financial accounting is the access to open financial markets, attraction of investments - primarily, due to sale of own securities.

Organizations of public sector include:

1. Bodies of government sector:

- national governments.

- regional bodies of governmental authority.

- local government bodies.

- public organizations (agencies, administrations, committees and companies).

2. Non-commercial public organizations.

Government organizations cover:

- government (municipal) institutions.

- state academies of sciences.

- governmental bodies. 
- governmental off-budget funds' regulatory bodies.

- territorial governmental off-budget funds' regulatory bodies.

The exception is the commercial organizations with government participation.

New standards of financial accounting of public sector have own numeration and contain thirty one standard, which are published on the site of Ministry of Finance of the Russian Federation.

The composition of financial accounting of public sector transformed in accordance with ISFA are drawn up by accrual method and includes the following statements:

1. Statement of financial position.

2. Statement of financial results.

3. Statement of net assets/capital change.

4. Statement of movement of funds.

5. Approved budgets.

6. Remarks.

In the international standards of financial accounting of public sector four standards expose many-faceted aspects concerning reflection in accounting of financial instruments (see Table 2).

Table 2. Standards that regulate accounting of financial instruments in accordance with international standards of financial accounting of public sector

\begin{tabular}{|c|c|c|c|}
\hline Standard number & Name of standard & Standard number (in Russia) & Name of standard (in Russia) \\
\hline IPSAS 15 & $\begin{array}{c}\text { Financial Instruments: Disclosure and } \\
\text { Presentation }\end{array}$ & МСФООС 15 & $\begin{array}{c}\text { Financial Instruments: Disclosure } \\
\text { and Presentation }\end{array}$ \\
\hline IPSAS 28 & Financial Instruments: Presentation & МСФООС 28 & $\begin{array}{c}\text { Financial Instruments: } \\
\text { Presentation of information }\end{array}$ \\
\hline IPSAS 29 & $\begin{array}{c}\text { Financial Instruments: Recognition } \\
\text { and Measurement }\end{array}$ & МСФООС 29 & $\begin{array}{c}\text { Financial Instruments: } \\
\text { Recognition and Measurement }\end{array}$ \\
\hline IPSAS 30 & Financial Instruments: Disclosures & МСФООС 30 & $\begin{array}{l}\text { Financial Instruments: } \\
\text { Disclosures. }\end{array}$ \\
\hline
\end{tabular}

International standards of financial accounting of public sector 28 on January 1, 2013 were replaced by ISFA of public sector 15 issued in 2001, however they remain in effect till ISFA 28 and ISFA 30 will be applied or become operative depending on what will happen first.

Organization of public sector use wide spectrum of such financial instruments as:

- receivables and accounts payable;

- multi-currency swaps for hedging of obligations in foreign currency.

To a lesser degree organizations of public sector apply:

- - equity instruments;

- combined debt instruments;

- combined equity instruments.

International standards of financial accounting of public sector contain requirements to presenting of balance financial instruments and define what information about balance (recognized) and off-balance (unrecognized) financial instruments should be exposed (see fig. 3).

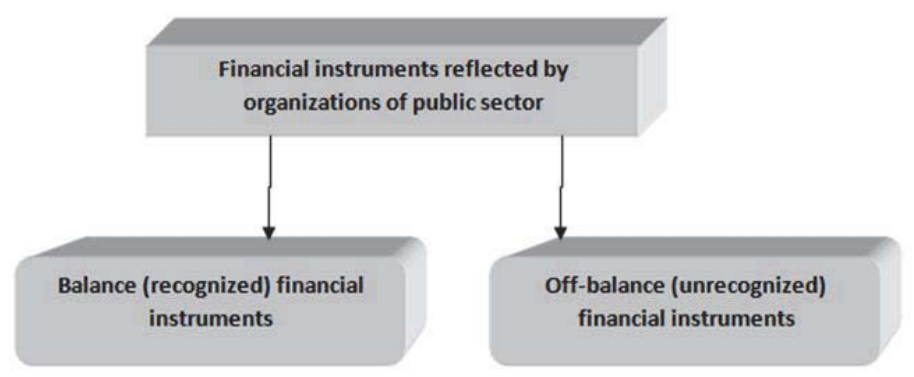

Figure 3 - Presentation of balance and off-balance financial instruments by organizations of public sector 
The presentations of information are applied for classification of financial instruments as obligatory and net assets/capital, related interests, dividends, incomes and expenses; and also to conditions, under which financial assets and financial obligations are subject to offset.

The information about financial instruments in financial accounting of public sector is exposed in the following aspects:

A) factors that influence volumes;

Б) interim periods and probability of future money flows of organizations related to financial instruments;

B) accounting policy applied in respect of these instruments.

Let's consider two main aspects on formation of "Financial instruments" indicator for accounting of public sector in accordance with International standards of financial accounting of public sector.

Aspect 1. Interests, dividends or analogous payments, losses and profits related to financial instrument or its component classified as financial obligation should be recognized as incomes or losses in framework of proficit or deficit (see fig. 4). The payments to holders of equity instrument should be referred by organization to decrease of net assets/capital minus privileges on income tax-related instrument. Transaction costs affecting net assets/capital should be taken into account as decrease of net assets/capital minus related privileges on income tax.

\begin{tabular}{|c|c|c|c|}
\hline \multicolumn{2}{|c|}{ Accounts correlation } & \multirow{2}{*}{ Name of articles } & \multirow{2}{*}{ Sum, c.u. } \\
\hline Debit & Credit & Interest expenses & 5990 \\
\hline Debit & & Financial obligations & 5990 \\
\hline
\end{tabular}

Figure 4 - Fragment of reflection of "Interest expenses" on financial obligations

Aspect 2. The cross charge of financial asset and financial obligation (see fig. 5). The financial asset and financial obligation should be set off, while net sum should be presented in Statement of financial position, only when organization:

a) currently has legally fixed right to perform offset of recognized sums;

intend either to perform net offset, or realize the asset and simultaneously discharge the obligation.

When accounting delivery of financial asset that does not meet the criteria for derecognition organization should not perform cross charge of delivered asset and corresponding obligation.

The conditions on financial instruments are not satisfied and the offset is unfeasible, as a rule, in the cases, when:

a) several different financial instruments are used for modeling of characteristics of one financial instrument (the "hybrid instrument");

b) financial assets and financial obligations originate from financial instruments, which possess similar primary risks (for example, the assets and obligations as a part of single portfolio of forward contracts or other derivative instruments), but different counterparts;

c) financial or other assets are pledged as the provision of financial instruments on a non-recourse basis;

d) financial assets are placed by debtor into trust for the purpose of performance of obligations, when the assets were not accepted by creditor in discharge of obligation (i.e. the agreement about organization of redemption fund);

e) obligations originated as a result of events led to losses should presumably be compensated by third party on the basis of requirement to insurance contract.

The cross charge of financial assets and obligations is considered in figure 5.

\begin{tabular}{|c|c|c|c|}
\hline \multicolumn{2}{|c|}{ Accounts correlation } & \multirow{2}{*}{ Name of articles } & \multirow{2}{*}{ Sum, c.u. } \\
\hline Debit & Credit & Financial assets & 480000 \\
\hline Debit & & Financial obligations & 480000 \\
\hline
\end{tabular}

Figure 5 - Fragment of cross charge of financial assets and obligations

As a result of conducted research we can make the following conclusions:

1. The formation of international standards of financial accounting of public sector is directly or indirectly dealt by five organizations. 
2. Four of thirty one standards are dedicated to financial instruments, whereupon ISFA PS 15 "Financial instruments: disclosure and presentation" was replaced by ISFA PS 28 "Financial instruments: presentation of information".

3. For making of financial reports in accordance with ISFA of public sector it is necessary to use modern software for transformation of accounting by Russian standards.

The regulatory framework being the basis of International standard of financial accounting of public sector 29 "Financial instruments: recognition and measurement" (Ministry of Finance of the Russian Federation, 2010) consists of the following list of standards issued earlier by International Standards of Financial Accounting Counsel under control of International Standards of Financial Accounting Committee:

1. International standard of financial accounting 39 "Financial instruments: recognition and measurement" (Ministry of Finance of the Russian Federation, 2011).

2. Specification of International Financial Accounting Explanation Committee 9 "Re-measurement of embedded derivative instruments" (IFAEC, 2012).

3. Specification of IFAEC 16 "Hedging of net investment to foreign activity" (IFAEC, 2012).

The foreign standard was made under control of such instances as:

- International financial accounting counsel (hereinafter referred to as IFAC);

- International public sector accounting standards counsel (hereinafter referred to as IPSASC);

- International Federation of Accountants (IFA, 2015);

- Fund of international standards of financial accounting (hereinafter referred to as FISFAC).

The international standards of accounting of public sector are designed for preparation of financial accounting by governments and other subject of public sector in all over the world. The standards are aimed at increase of quality, coordination and visibility of financial accounting in public sector in all over the world, presentation of recommendations to counterparts, facilitation of communicational interrelations between accountants, employees of public sector, building of trust to public sector, development of strong international economy by means of creation and strengthening of the regime of high-quality professional standards.

The international standards of financial accounting of public sector 29 have fixed the regulations for recognition and measurement of financial instruments (Ministry of Finance of the Russian Federation, 2010). In this connection we should figure out general moments of set rules on initial recognition and derecognition of financial assets and financial obligations (see fig. 6).

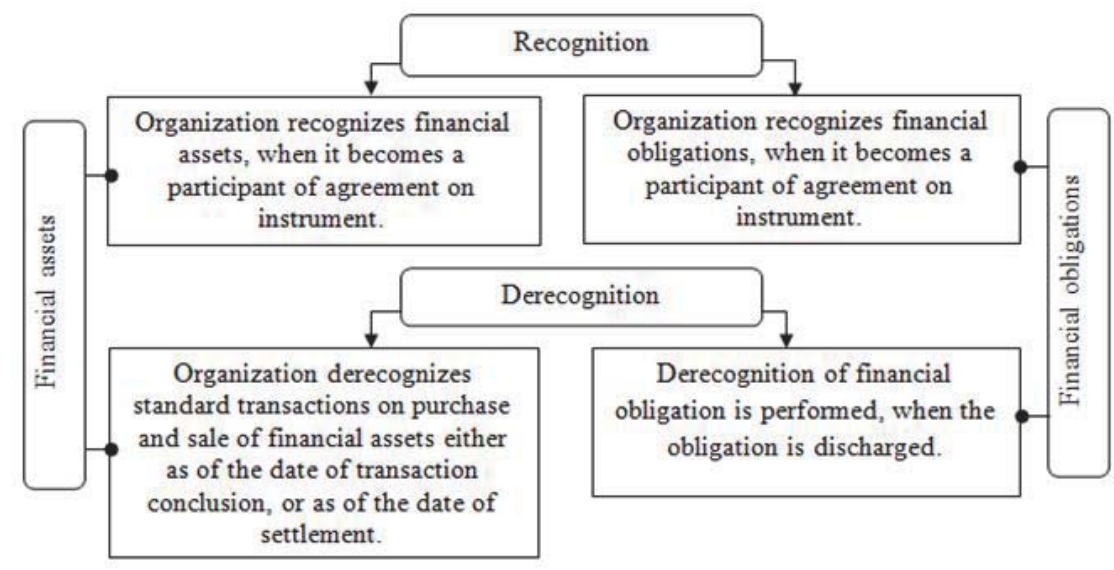

Figure 6 - Initial recognition and derecognition of financial assets and obligations in accordance with international standard of financial accounting of public sector 29

In Table 3 there is detailed information on derecognition and initial recognition of standard transactions with financial assets and derivative financial instruments (hereinafter referred to as DFI). 
Table 3. Initial recognition and derecognition of transactions of purchase and sale of financial assets and DFI

\begin{tabular}{|l|c|c|c|c|}
\hline \multirow{2}{*}{ Type of financial asset } & \multicolumn{2}{|c|}{ Recognition } & \multicolumn{2}{|c|}{ Derecognition } \\
\cline { 2 - 5 } & $\begin{array}{c}\text { Date of transaction } \\
\text { conclusion }\end{array}$ & $\begin{array}{c}\text { Settlement } \\
\text { date }\end{array}$ & $\begin{array}{c}\text { Date of transaction } \\
\text { conclusion }\end{array}$ & $\begin{array}{c}\text { Settlement } \\
\text { date }\end{array}$ \\
\hline Standard transaction of purchase and sale of financial assets & $\checkmark$ & $\checkmark$ & $\checkmark$ & $\checkmark$ \\
\hline Derivative financial instruments & $\checkmark$ & & & $\checkmark$ \\
\hline
\end{tabular}

After structural working out of the matter of initial recognition and derecognition of financial assets, financial obligations and derivatives it will be logical to come to studying of primary and subsequent measurement of financial instruments by organizations of public sector in accordance with international standard of financial accounting of public sector 29 (Ministry of Finance of the Russian Federation, 2010). The present matter is represented in detail in author's Table 4. On the basis of international standard of financial accounting of public sector 29 that gradually regulates measurement of financial assets and obligations (Ministry of Finance of the Russian Federation, 2010) we will develop a formula on calculation of subsequent measurement of financial instruments by four typical categories.

Author's method for calculation of subsequent measurement of category II - the investments held to maturity:

$\mathrm{SMIhm}=\mathrm{Ac}-\|$,

where SMIhm - subsequent measurement of investments held to maturity;

Ac - amortized cost;

II - impairment losses.

Table 4. Author's grouping of material on initial and subsequent measurement of financial assets and obligations regulated by international standard of financial accounting of public sector 29 (Ministry of Finance of the Russian Federation, 2010)

\begin{tabular}{|c|c|c|c|c|}
\hline Initial measurement & \multicolumn{4}{|c|}{ Financial assets and obligations are initially measured by fair value. } \\
\hline \multirow{7}{*}{$\begin{array}{l}\text { Subsequent } \\
\text { measurement }\end{array}$} & \multicolumn{4}{|c|}{ Transaction costs should not be included to initially recognized cost } \\
\hline & \multicolumn{4}{|c|}{ IV categories of subsequent measurement of financial assets } \\
\hline & $\begin{array}{c}\text { Financial assets } \\
\text { considered by fair } \\
\text { value }\end{array}$ & $\begin{array}{l}\text { Investments held to } \\
\text { maturity }\end{array}$ & Loans and receivables & Financial assets being available for sale \\
\hline & $\begin{array}{l}\text { Changes of fair } \\
\text { value are } \\
\text { reflected as a } \\
\text { part of proficit or } \\
\quad \text { deficit }\end{array}$ & \begin{tabular}{|l|} 
Are measured by \\
amortized cost minus \\
impairment losses. \\
The impairment losses \\
are recognized as a \\
part of proficit or deficit
\end{tabular} & $\begin{array}{l}\text { Are measured by } \\
\text { amortized cost minus } \\
\text { impairment losses. The } \\
\text { impairment losses are } \\
\text { recognized as a part of } \\
\text { proficit or deficit }\end{array}$ & $\begin{array}{c}\text { Are measured by fair value, while changes of } \\
\text { fair value are recognized directly as a part of net } \\
\text { assets/capital. The impairment losses sustained } \\
\text { on instruments being in availability for sale are } \\
\text { recognized as a part of proficit or deficit, not as } \\
\text { a part of net assets/capital. }\end{array}$ \\
\hline & \multicolumn{4}{|c|}{ Subsequent measurement of other instruments that are not being a part of 4 categories } \\
\hline & \multicolumn{2}{|c|}{ Investments in equity instruments } & \multicolumn{2}{|c|}{$\begin{array}{l}\text { Financial obligations, except for financial obligations considered by fair } \\
\text { value }\end{array}$} \\
\hline & \multicolumn{2}{|c|}{$\begin{array}{l}\text { The present type of financial instruments } \\
\text { cannot be measured by fair value by } \\
\text { virtue of impossibility of reliable } \\
\text { determination of fair value, so they are } \\
\text { measured by prime cost minus } \\
\text { impairment losses. }\end{array}$} & \multicolumn{2}{|c|}{$\begin{array}{l}\text { Are measured by amortized cost, the changes of which are reflected as a } \\
\text { part of proficit or deficit, financial guarantees, obligations that originate } \\
\text { when delivering financial assets. }\end{array}$} \\
\hline
\end{tabular}

On the basis of Table 4 we will present the accounting instrumentation for subsequent measurement of the third category of financial instruments in accordance with international standard of financial accounting of public sector 29 (Ministry of Finance of the Russian Federation, 2010) , loans and receivables.

$\mathrm{SMLR}=\mathrm{AC}-\| \mathrm{I}$,

where SMLR - subsequent measurement of loans and receivables,

Ac - amortized cost;

II - impairment losses.

The ambiguous position is taken by investments in equity instruments, which by virtue of impossibility of reliable determination of fair value should be measured by amortized cost. There is author's adaptation basis for calculation of subsequent measurement of sought financial instruments: 
SMIEI = PCFI $-\|$,

where SMIEI - subsequent measurement of investments in equity instruments;

PCFI - prime cost of financial instrument (investments in equity instruments);

II - impairment losses.

The offered author's adaptation calculation and methodic basis for determination of subsequent measurement of such financial instruments as loans and receivables, investments in equity instruments held to maturity - can become a support for counterparts, which for the first time face transformation of Russian system of accounting reporting to foreign standards and particularly - the category of organizations related to public sector.

After detailed study of initial recognition and derecognition of financial assets and obligations, development of author's adaptation calculation and methodic basis for determination of subsequent measurement of financial instruments the topical matter is the withdrawal of financial asset. ISFA 29 regulates the withdrawal of financial asset to the full extent as the difference between balance cost and sum of obtained compensation (including all the newly obtained assets minus all the newly adopted obligations) and the whole accumulated profit or loss, which were earlier recognized as a part of net assets/capital, is recognized as a part of proficit or deficit (Ministry of Finance of the Russian Federation, 2010). On the assumption of the standard we will present author's adaptation calculation formula for determination of fair value being a part of proficit/deficit due to withdrawal of financial asset to the full extent:

P/D DFA (fe) $=$ BCfa $-(\mathrm{OC}+(\mathrm{NOS}-\mathrm{NAO})+\mathrm{P} / \mathrm{L})$,

where P/D DFA (fe) - proficit/deficit due to withdrawal of financial asset to the full extent;

BCfa - balance cost of financial asset,

OC - obtained compensation;

NOS - newly obtained assets;

NAO - newly accepted obligations;

$\mathrm{P} / \mathrm{L}$ - accumulated profit/loss earlier recognized as a part of net assets/capital.

In the case when asset is interpreted with bigger asset (i.e. becomes its part), the minor part is fully subject to withdrawal, while the rest asset, the recognition of which is proceeded, remains in organization. On the basis of international standard of financial accounting 29 we will develop the adaptation method for withdrawal of one of the parts of bigger asset using the definition: the difference between balance cost referred to the part, the recognition of which was ceased, and the sum of compensation obtained for the part, the recognition of which was ceased (including all the newly obtained assets minus all the accepted obligations) and the whole accumulated profit or loss, which earlier were recognized as a part of net assets/capital, is recognized as a part of proficit or deficit (Ministry of Finance of the Russian Federation, 2010) .

On the basis of above-specified international standard we will make a formula for calculation of fair value of withdrawal of minor part of big financial asset:

P/D Wfa (pe) $=$ BCpfa $-(\mathrm{OCp}+(\mathrm{NOA}-\mathrm{NAO})+\mathrm{P} / \mathrm{L})$,

where P/D Wfa (pe) - proficit/deficit due to withdrawal of financial asset to the partial extent, the recognition on which was ceased;

BCpfa - balance cost of a part of financial asset (the recognition on which was ceased);

OCp - obtained compensation for the part, the recognition on which was ceased;

NOA - newly obtained assets;

NAO - newly accepted obligations;

$\mathrm{P} / \mathrm{L}$ - accumulated profit/loss earlier recognized as a part of net assets/capital.

In case of absence on market of price quotations or transactions, with help of which one could substantiate the fair value of a part of asset subject to further recognition, the best indicator of fair value is the difference between the fair value of main financial asset as a whole and the compensation. On the basis of paragraph 30 of international standard of financial accounting of public sector 29 (Ministry of Finance of the Russian Federation, 2010) we will make adaptation calculation base for determination of fair value of a part of financial asset that was recognized ceased:

$\mathrm{FVpfa}=\mathrm{FVbfa}-\mathrm{OC}(\mathrm{pfa})$,

where FVpfa - fair value of a part of financial asset;

FVbfa - fair value of big financial asset as a whole;

OC (pfa) - compensation for a part of asset that was recognized ceased obtained from receiving party.

Author's adaptation calculation formulas for determination of fair value of fully withdrew financial asset (see Formula 5) and its part (see Formula 6). It will be logical to develop the formula for fair value of withdrew (derecognition) financial asset (or a part of financial obligation) that should be referred to proficit/deficit:

$F V$ wfo $=B C$ d/d fo $-(P C+D U A+A O)$, 
where FV wfo - fair value of withdrew financial obligation;

$\mathrm{BC} \mathrm{d} / \mathrm{d}$ fo - balance cost of discharged/delivered to other party financial obligation (or its part);

PC - paid compensation;

DUA - delivered unreliable assets;

AO - accepted obligations.

Authors have worked out the adaptation methods for calculation of fair value of financial asset and its part, financial obligation and its part. The offered base can serve the good turn for employees of financial department, account department and other financial-and-economical services of public sector.

Next, we will move to the creation of final author's method for determination of initial fair value of financial instruments reflection, in case if financial asset or financial obligations are not measured by fair value. Paragraph 45 of international standard of financial accounting of public sector 29 (Ministry of Finance of the Russian Federation, 2010) regulates the operation that suggests that fair value is added with transactional expenditures directly linked to acquisition or issuing of financial asset of financial obligation:

$\mathrm{FV} I \mathrm{IM}$ fa/fo $=\mathrm{FV}$ fi $+\mathrm{TE}$,

where FV IM fa/fo - fair value of initial measurement of financial asset or financial obligation;

$\mathrm{FV} \mathrm{fi} \mathrm{-} \mathrm{fair} \mathrm{value} \mathrm{of} \mathrm{financial} \mathrm{instrument;}$

$\mathrm{TE}$ - transactional expenditures.

\section{Discussion}

\subsection{Evaluation of the shingles algorithm implementation results}

As a result of hypothetico-induction and hypothetico-deduction cognition method, analysis, synthesis and generalization, which were used during making of the article, authors succeed in obtaining the following results that refer to scientific novelty in world research community:

1) on the basis of analysis, synthesis and generalization of theoretical data Table 3 and figure 6 on initial recognition and derecognition of transactions of purchase and sale of financial assets, obligations and derivatives were made;

2) the result of application of hypothtico-induction method of scientific cognition is the Table 4 being the fundamental for application of hypothtico-deduction method of scientific cognition;

3) author's adaptation formula for calculation of subsequent measurement of investments held to maturity;

4) author's calculation instrumentation on subsequent measurement of loans and receivables;

5) author's adaptation base for calculation of subsequent measurement of investments in equity instruments;

6) author's adaptation calculation formula for determination of fair value due to withdrawal of financial asset to the full extent;

7) author's measurement method for calculation of fair value of withdrawal of minor part of big financial asset;

8) adaptation calculation base for determination of fair value of a part of financial asset that was recognized ceased;

9) author's formula for fair value of withdrew (derecognition) financial obligation (or a part of financial obligation);

10) adaptation calculation instrumentation for determination of fair estimated value of financial instruments' reflection, in case if financial asset or financial obligation are not measured by fair value.

\subsection{Evaluation of the results of the key phrases search modules}

The transformation of accounting and financial reporting by organization of public sector is like a revolution, for if we consider the changes and reforms in retrospective key, we can conclude that the present area of knowledge had been remaining static for quite a long time, while the $21^{\text {st }}$ century is the time of significant structural transformations, i.a. - in financial instruments. It is necessary to note that Russia is not a leader in application of international standards of public sector. The leading countries in this area are: USA, Australia, New Zeland, Peru, Romania, etc. The Russian Federation has adopted the international standards of financial accounting of public sector with account of experience of other leading countries and will use the developed conceptual aspects. Financial assets and obligations (financial instruments) are quickly-developing instruments (together with such special instruments as derivative ones), which are being necessary for government during crisis. 


\section{Conclusion}

We'd like to note that the aspects of implementation of international standards of financial accounting of public sector is being for today the most relevant matter for budget organizations, as far as budget planning takes special position in financial activity of any company that forecasts incomes and losses. In the article we have discussed conceptual and methodic aspects of formation of such matters as "financial assets" and "financial obligations" in accounting of organizations of public sector.

\section{References}

Chan, J. L. (2008). International public sector accounting standards: Conceptual and institutional issues. Retrieved from http:/l jameslchan.com/papers/Chan2008IPSAS3.pdf (access date 27.01.2015)

Explanation of IFRIC 9 "Reassessment embedded derivatives" (Ed. as of 18.07.2012) (put in force within the territory of the Russian Federation by the order of the Ministry of Finance of Russia as of 25.11.2011 N 160H).

Collection of International Accounting Standards of public sector 29 "Financial Instruments: Recognition and Measurement". Edition of 2010. Official translation. 2012. ISBN 978-5-9551-0573-4, $1148 \mathrm{p}$.

Tabalina S. A., Gradutsky A. G. (2012). Development of accounting and reporting in public management sector. Budzhetny uchet. Retrieved from: http://b-uchet.ru/article/186625.php (access date: 27.01.2015).

Tabalina S. A. (2001). International public sector accounting standards. Voprosy gosudarstvennogo i munitsipalnogo upravleniya, 3, pp. 49-61.

Dombrovskaya E. N. (2012). On application of IFRS in public sector of Russian economy. Mezhdunarodny buhgaltersky uchet, 34 (232). Retrieved from: http://www.fin-izdat.ru/journal/interbuh/list.php?SECTION_ID=3480 (access date 27.01.2015)

International Accounting Standard (IAS) 39 "Financial instruments: recognition and measurement" (Ed. as of 24.12.2013) (put in force within the territory of the Russian Federation by the order of the Ministry of Finance of Russia as of 25.11.2011 N 160H). Retrieved from: http://old.minfin.ru/rulaccounting/mej_standart_fo/msfo_ob/index.php?id_4=15879(access date 27.01.2015).

International Accounting Standard (IFRS) 11 "Joint activity" (Ed. as of 30.10.2014) (put in force within the territory of the Russian Federation by the order of the Ministry of Finance of Russia as of 18.07.2012 N 106H). Explanation of IFRIC 16 "Hedging of net investment into foreign operation. Retrieved from: http://base.consultant.ru/cons/cgi/online.cgi?req=doc;base=LAW;n=171599 (access date: 27.01.2015).

Official site of International Federation of Accountants. Retrieved from: http://www.ifac.org (access date 17.01.2015).

Official site of the Ministry of Finance of the Russian Federation. IFRS 15 - Financing instruments: disclosure and presentation. Retrieved from: http://old.minfin.ru/ru/budget/sfo/msfo/ (access date: 15.12.2014).

Official site of the Ministry of Finance of the Russian Federation. IFRS 28 - Financing instruments: representation of information. Retrieved from: http://old.minfin.ru/ru/budget/sfo/msfo/ (access date: 15.12.2014).

Official site of the Ministry of Finance of the Russian Federation. IFRS 29 - Financing instruments: recognition and measurement. Retrieved from: http://old.minfin.ru/ru/budget/sfo/msfo/ (access date: 15.12.2014).

Official site of the Ministry of Finance of the Russian Federation. IFRS 30 - Financing instruments: information disclosure. Retrieved from: http://old.minfin.ru/ru/budget/sfo/msfo/ (access date: 15.12.2014). 